\title{
PEMBUATAN NANOPARTIKEL PERAK (NPP) DENGAN BIOREDUKTOR EKSTRAK BUAH Muntingia calabura L UNTUK ANALISIS LOGAM MERKURI
}

\author{
Purwo Ismaya Sari ${ }^{* 1}$, M. Lutfi Firdaus ${ }^{2}$, Rina Elvia ${ }^{3}$ \\ Program Studi Pendidikan Kimia Fakultas Keguruan dan Ilmu Pendidikan Universitas Bengkulu \\ ${ }^{1,2,3 .}$ Program Studi Pendidikan Kimia, Jurusan PMIPA, FKIP, Universitas Bengkulu \\ e-mail : ${ }^{1}$ purwo.ismayasari@gmail.com
}

\begin{abstract}
The goal of this research was to make silver nanoparticles (NPP) with a cherry fruit extract bioreductor which was used for mercury metal analysis by using a digital image method. The process of making silver nanoparticles had done by a bottom up method involving a reduction reaction. The precursors used were $1 \mathrm{mM} \mathrm{AgNO3} \mathrm{solution} \mathrm{and} \mathrm{as} \mathrm{a} \mathrm{bioreductor} \mathrm{was} \mathrm{an} \mathrm{antioxidant}$ compound which were in cherry fruit extract. Variation of the volume ratio between cherry fruit extract and $1 \mathrm{mM}$ AgNO3 solution was $1: 3,1: 4,1: 5,1: 6$, and $1: 7$ and the variation of contact time were 5, 15, 30, 45, 1, 2, 3 hours, and 1, 2, 7 days. The most optimum results of silver nanoparticles were synthesized with $1: 4$ volume ratio and 1 hour contact time. From the results of selectivity test, it was known that silver nanoparticles were made selective toward $\mathrm{Hg}$ and Fe metal. The sensitivity test toward $\mathrm{Hg}$ metal, it was known that NPP can detect mercury metal with the smallest concentration of 16,7 ppb.
\end{abstract}

Keywords : Silver nanoparticles, Muntingia calabura L, mercury, digital image

\section{Abstrak}

Penelitian ini bertujuan untuk mensintesis nanopartikel perak (NPP) dengan bioreduktor ekstrak buah Muntingia calabura $L$ (kersen) yang digunakan untuk analisis logam merkuri dengan menggunakan metode citra digital. Proses pembuatan nanopartikel perak dilakukan dengan metode bottom up yang melibatkan reaksi reduksi. Prekursor yang digunakan adalah larutan $\mathrm{AgNO}_{3} 1 \mathrm{mM}$ dan sebagai bioreduktor adalah senyawa antioksidan yang ada di ekstrak buah $M$. calabura $L$. Variasi perbandingan volume ekstrak buah M.calabura $L$ dengan larutan $\mathrm{AgNO}_{3} 1 \mathrm{mM}$ adalah $1: 3,1: 4,1: 5,1: 6$, dan $1: 7$ dan variasi waktu kontak adalah 5, 15, 30, 45, 60 menit, 1, 2, 3 jam, dan 1, 2, 7 hari. Hasil nanopartikel perak yang paling optimum disintesis dengan perbandingan volume $1: 4$ dan waktu kontak 1 jam. Hasil uji selektivitas menunjukkan bahwa nanopartikel perak yang dibuat selektif terhadap logam Hg dan Fe. NPP mampu mendeteksi logam merkuri dengan konsentrasi terkecil 16,7 pbb.

Kata kunci : Nanopartikel perak, Muntingia calabura L, logam merkuri, citra digital.

\section{PENDAHULUAN}

Salah satu pencemaran yang terjadi di Indonesia akibat proses pembangunan adalah pencemaran logam merkuri akibat limbah industri dan alam, karena banyaknya pemanfaatannya pada berbagai produk - produk industri seperti pada produk krim pemutih wajah, dimana logam merkuri kadang-kadang ditambahkan ke dalam krim pemutih untuk menghalangi pembuatan melanin [1]. Pemakaian merkuri dalam krim pemutih dapat menimbulkan bintik-bintik hitam pada kulit, alergi, iritasi kulit serta pemakaian dengan dosis tinggi dapat menyebabkan kerusakan permanen otak, ginjal, dan gangguan perkembangan janin bahkan paparan jangka pendek dalam dosis tinggi juga dapat menyebabkan muntah-muntah, diare dan kerusakan paru-paru serta merupakan zat karsinogenik [2]. Oleh sebab itu perlu dilakukan pendeteksian dan analisis kadar logam merkuri pada krim pemutih yang akurat serta sensitif, salah satunya melalui analisa kolorimetri dengan menggunakan citra digital . Data citra digital dapat diperoleh dari pemindai, webcam, kamera digital dan ponsel beserta perangkat coupling (CCD) atau sensor semikonduktor oksida logam (CMOS) komplementer [3]. Nanopartikel perak (NPP) memiliki keunggulan dibandingkan dengan nanopartikel emas karena sifat optis NPP lebih baik [4], sehingga NPP dapat digunakan sebagai detektor dan sekaligus sebagai indikator pewarnaan (kolorimetri) untuk menganalisis kadar logam merkuri menggunakan metode citra digital. Ambang batas penambahan logam merkuri dalam krim pemutih sebesar 70 ppm [5], maka kesensitifan deteksi nano-partikel perak yang dipakai haruslah mampu mengukur pada konsentrasi yang lebih rendah dari konsentrasi ambang batas.

Tujuan penelitian ini ialah untuk mensintesis nanopartikel perak dengan bioreduktor ekstrak buah M. calabura $L$ yang sensitif dalam mengukur kadar logam merkuri pada krim pemutih dengan metode citra digital.

\section{METODE PENELITIAN}

Penelitian ini dilaksanakan di Laboratorium Program Studi Pendidikan Kimia, Fakultas Keguruan dan Ilmu Pendidikan (UNIB) dan Laboratorium Agro- 
nomi, Fakultas Pertanian (UNIB) pada bulan Desember 2016 sampai dengan bulan Mei 2017.

Alat yang digunakan pada penelitian ini ialah : neraca analitik, labu ukur, gelas kimia, erlenmeyer, botol vial, botol semprot, gelas ukur, hot plate, termometer, corong, pipet volumetri, bola hisap, pipet mikro, pipet tetes, sudip, cutter, nampan, tissu, lumpang, alu, kaca arloji, oven, kamera (Fuji Film Finepix S2980), mini studio buatan sendiri, kuvet, Biospektrometer Eppendorf..

Bahan yang digunakan pada penelitian ini adalah buah M.calabura $L$, aquades, aqua DM, $\mathrm{HgCl}_{2}, \mathrm{AgNO}_{3}, \mathrm{CaCl}_{2}, \mathrm{Al}\left(\mathrm{NO}_{3}\right)_{3} 9 \mathrm{H}_{2} \mathrm{O}, \mathrm{Co}\left(\mathrm{NO}_{3}\right)_{2}$. $6 \mathrm{H}_{2} \mathrm{O}, \mathrm{Cr}\left(\mathrm{NO}_{3}\right)_{3} .9 \mathrm{H}_{2} \mathrm{O}, \mathrm{CuSO}_{4} \cdot 5 \mathrm{H}_{2} \mathrm{O}, \mathrm{FeCl}_{3} .6 \mathrm{H}_{2} \mathrm{O}$, $\mathrm{FeCl}_{2} . \quad 4 \mathrm{H}_{2} \mathrm{O}, \quad \mathrm{KCl}, \quad \mathrm{MgCl}_{2} \cdot 6 \mathrm{H}_{2} \mathrm{O}, \quad \mathrm{MnSO}_{4} \cdot \mathrm{H}_{2} \mathrm{O}$, $\mathrm{NiSO}_{4} \cdot 6 \mathrm{H}_{2} \mathrm{O}, \mathrm{NaCl}, \mathrm{Pb}\left(\mathrm{NO}_{3}\right)_{2}, \mathrm{ZnCl}_{2}$, larutan standar Arsen dan Kadnium, aquaregia, krim pemutih merk $\mathrm{x}$,aluminium foil dan kertas saring.

Seluruh alat berbahan gelas yang akan digunakan dicuci dengan detergen, kemudian dibilas dengan air sampai bersih. Selanjutnya dicuci kembali dengan $\mathrm{HCl} 2 \mathrm{M}$ dan dibilas dengan aquades hingga bersih, terakhir dibilas lagi dengan air demineralisasi.

Buah M.calabura $L$ yang sudah dicuci ditimbang sebanyak $20 \mathrm{~g}$. Selanjutnya dimasukkan ke dalam gelas kimia $150 \mathrm{~mL}$ dan ditambahkan air de-mineralisasi sebanyak $100 \mathrm{~mL}$ lalu dipanaskan selama 15 menit pada suhu larutan $80{ }^{\circ} \mathrm{C}$ dengan ditutup menggunakan aluminium foil. Selanjutnya, air rebusan buah M.calabura $L$ disaring.

Variasi perbandingan volume ekstrak buah Muntingia calabura $\mathrm{L}$ dengan larutan $1 \mathrm{mM} \mathrm{AgNO}_{3}$ terlihat pada Tabel 1 di bawah ini

Tabel 1. Perbandingan ekstrak buah kersen dengan larutan $1 \mathrm{mM} \mathrm{AgNO}_{3}$

\begin{tabular}{ccc}
\hline Perbandingan & Vol. $(\mathrm{mL})$ & Vol. $\mathrm{AgNO}_{3}(\mathrm{~mL})$ \\
\hline $1: 3$ & 6 & 18 \\
$1: 4$ & 5 & 20 \\
$1: 5$ & 4 & 20 \\
$1: 6$ & 3 & 18 \\
$1: 7$ & 3 & 21 \\
\hline
\end{tabular}

Setelah itu campuran ekstrak buah M. Calabura $\mathrm{L}$ dan $\mathrm{AgNO}_{3}$ disinari matahari dengan va-riasi waktu 5, 15, 30, 45, 60 menit dan kemudian di ambil sebanyak $\pm 2 \mathrm{~mL}$. NPP kemudian diukur dengan spektrofotometer UV-Vis pada panjang gelombang 280-700 nm. Penyinaran pada biosintesis NPP dilakukan secara tidak langsung. Setelah penyinaran kemudian sampel diletakan di dalam ruangan lalu diamati sampai dengan 7 hari.
Larutan logam standar yang akan dibuat adalah larutan ion logam $\mathrm{Al}^{3+}, \mathrm{Ca}^{2+}, \mathrm{Cr}^{3+}, \mathrm{Co}^{2+}, \mathrm{Cu}^{2+}$, $\mathrm{Fe}^{2+}, \mathrm{Fe}^{3+}, \mathrm{Hg}^{2+}, \mathrm{K}^{+}, \mathrm{Mg}^{2+}, \mathrm{Na}^{+}, \mathrm{Mn}^{2+}, \mathrm{Ni}^{2+}, \mathrm{Pb}^{2+}, \mathrm{Zn}^{2+}$, As dan $\mathrm{Cd}^{2+}$ (untuk melihat selektivitas NPP terhadap logam). Larutan logam standar dibuat dengan konsentrasi awal $1000 \mathrm{ppm}$ dengan cara menghitung massa masing-masing garam logam, ditimbang sesuai dengam massa yang didapatkan dan dilarutkan dalam labu ukur $50 \mathrm{~mL}$. Larutan standar logam $\mathrm{Hg}$ juga dibuat dengan konsentrasi awal 1000 ppm dengan menimbang serbuk $\mathrm{HgCl}_{2}$ sebanyak $67,75 \mathrm{mg}$, kemudian dilarutkan di dalam labu ukur $50 \mathrm{~mL}$ dengan air demineralisasi sampai tanda batas. Kemudian digoncang-goncangkan. Larutan standar arsen dan kadmium diambil dari larutan standar yang sudah ada.

Uji selektivitas NPP dilakukan dengan memasukkan $2 \mathrm{~mL}$ NPP yang dibuat pada kondisi optimum ke dalam masing-masing botol vial, selanjutnya ditambahkan $0,2 \mathrm{~mL}$ dari setiap logam standar dengan konsentrasi 90,1 ppm. Kemudian diamati perubahan warnanya dan diukur absorbansinya. Selektivitas NPP ditentukan dengan mengetahui perubahan warna menjadi bening dan perubahan absorbansi paling besar pada masing-masing penambahan logam.

Uji sensitivitas NPP dilakukan dengan memasukkan $2 \mathrm{~mL}$ NPP yang dibuat pada kondisi optimum ke dalam masing-masing botol vial, selanjutnya ditambahkan $1 \mathrm{~mL}$ logam $\mathrm{Hg}$ masing-masing dengan konsentrasi setelah pencampuran adalah $0 ; 0,3 ; 6,7$; 13,$3 ; 30 ; 26,7 ; 33,3 ; 50 ; 66,7 ; 83,3$ ppm dan konsentrasi setelah pencampuran adalah $0 ; 0,7 ; 3,3 ; 6,7$; 16,$7 ; 33,3 ; 66,7 ; 133,3 ; 200 ; 266,7$ ppb. Kemudian diamati perubahan warna yang terjadi dan diukur absorbansinya. Sensitivitas NPP ditentukan dengan melihat campuran yang mulai mengalami perubahan warna dibandingkan dengan larutan blanko kemudian dimasukkan ke dalam mini studio dan difoto. Uji sensitivitas lebih lanjut diketahui dengan menentukan batas deteksi pada bagian teknik analisis data.

Kurva kalibrasi metode spektrofotometri UVVis dibuat dengan memplotkan nilai absorbansi (A) Vs konsentrasi (ppm) dari data yang diperoleh pada panjang gelombang optimum larutan blanko menggunakan Microsoft Excel 2007. Persamaan linear yang diperoleh adalah :

$$
y=m x+c
$$

Keterangan : $\quad y=$ absorbansi $x=$ konsentrasi

$$
\mathrm{m}=\text { gradien } \quad \mathrm{c}=\text { intersep }
$$

Kurva kalibrasi metode Citra Digital dibuat dengan mengolah terlebih dahulu foto yang diperoleh. Langkah-langkah yang dilakukan adalah : a) Gambar dari masing-masing campuran NPP dan larutan standar dicrop menggunakan Photoshop CS6 dengan ukuran 
$1,02 \mathrm{~cm} \times 1,02 \mathrm{~cm}$ pada bagian yang kepekatan warnanya paling merata. b) hitung nilai komponen warna RGB-nya menggunakan MATLAB R2010b.dan c) hitung nilai intensitas serapan (A) masing-masing komponen warna RGB-nya menggunakan Microsoft Excel 2007 dengan persamaan :

$$
\mathrm{A}=\log \left(\frac{\mathrm{I}_{0}}{\mathrm{I}_{\mathrm{t}}}\right)
$$

Keterangan : $\mathrm{A}=$ intensitas serapan komponen warna

$\mathrm{I}_{0}=$ nilai komponen warna larutan blanko

$\mathrm{I}_{\mathrm{t}}=$ Nilai komponen warna larutan standar

Persamaan linear Metode Citra Digital-SLR diperoleh dengan memplotkan intensitas serapan $R, G$, dan B Vs konsentrasi menggunakan Microsoft Excel 2007. Persamaan linear dengan gradient (kemiringan) dan koefisien determinasi $\left(\mathrm{R}^{2}\right)$ paling besar digunakan untuk menentukan konsentrasi sampel yang akan dianalisis. Pembuatan kurva perbandingan dilakukan dengan memplotkan konsentrasi larutan standar yang didapat menggunakan metode spektrofomerti UV-Vis terhadap konsentrasi larutan standar yang didapat dengan metode citra digital. konsentrasi larutan standar yang didapat menggunakan metode spektrofomerti UV-Vis sebagai sumbu $\mathrm{x}$ dan konsentrasi larutan standar yang didapat dengan metode citra digital sebagai sumbu $y$.

\section{HASIL DAN PEMBAHASAN}

Penyinaran dilakukan secara tidak langsung untuk menghindari NPP terbentuk banyak atau pekat. Keberhasilan terbentuknya NPP ditandai dengan adanya perubahan warna dari bening menjadi kuning hingga kuning kecoklatan seiring dengan bertambahnya waktu penyinaran serta adanya puncak serapan pada panjang gelombang 400-450 nm pada pengukuran menggunakan spektrosfotometer UV-Vis yang merupakan nilai Surface Plasmon Resonances (SPR) dari nanopartikel perak [6]. Perubahan warna proses biosintesis ditampilkan pada Gambar 1.

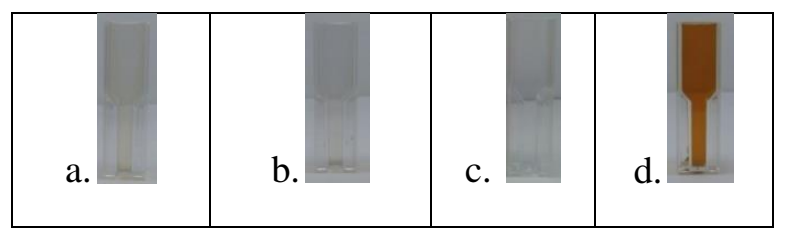

Gambar 1. Perubahan warna, a). Ekstrak buah M. calabura L, b). Larutan $\mathrm{AgNO}_{3}$, c). Aqua DM , dan d). NPP

Ekstrak buah M.calabura $L$ yang berwarna kuning pudar dicampurkan dengan larutan $\mathrm{AgNO}_{3}$ $1 \mathrm{mM}$ yang berwarna bening berubah warna menjadi kuning kecoklatan. Hasil ini mengindikasikan campuran tersebut telah terbentuk NPP.

Terbentuknya NPP juga diukur dengan spektrofotometer UV-Vis yang dapat dilihat pada Gambar 2.

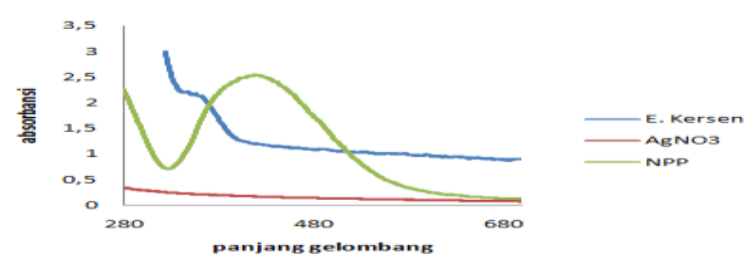

Gambar 2. Spektrum serapan spektrofotometer UV-Vis dari proses biosintesis NPP

Hasil spektrum serapan spektrofotometer UVVis pada larutan $\mathrm{AgNO}_{3} 1 \mathrm{mM}$ menunjukkan tidak adanya puncak serapan pada daerah Visible. Pada ekstrak buah M.calabura $L$ terdapat serapan pada daerah Visible tetapi tidak terbentuk puncak. Adanya serapan dikarenakan ekstrak buah M.calabura $L$ berwarna sehingga memiliki nilai absorbansi. Kemudian setelah kedua larutan tersebut bercampur dan dibantu dengan penyinaran oleh sinar matahari spektrum serapannya memiliki puncak pada panjang gelombang kisaran 400-450 nm. Dari warna dan spektrum serapan yang terbentuk, campuran tersebut telah terbentuk NPP.

Biosintesis NPP ini terjadi karena di dalam ekstrak buah M.calabura $L$ terdapat senyawa antioksidan sebagai bioreduktor seperti vitamin C sebesar $90 \mathrm{mg}$ per $100 \mathrm{~g}$ [7] dan flavonoid. sebesar $0,98 \mathrm{mg} / \mathrm{g}$ [8]. Dugaan kuat bahwa vitamin $\mathrm{C}$ dan flavonoid yang terkandung yang menjadi bioreduktor karena senyawa tersebut memiliki gugus -OH yang mampu untuk mendonorkan proton.Jika dilihat dari data potensial reduksi, dari $\mathrm{Ag}^{+}$sebesar $+0,80 \mathrm{~V}$, maka vitamin $\mathrm{C}$ dan flavonoid dapat mereduksi ion $\mathrm{Ag}^{+}$. Hal ini dikarenakan potensial reduksi vitamin $\mathrm{C}$ dan flavonoid di bawah potensial reduksi dari $\mathrm{Ag}^{+}$yaitu $+0,35 \mathrm{~V}$ dan $+0,33 \mathrm{~V}$ sehingga akan dapat mereduksi ion $\mathrm{Ag}^{+}$ menjadi $\mathrm{Ag}^{0}$ yang merupakan nanopartikel perak. Contoh mekanisme reaksi reduksi vitamin $\mathrm{C}$ dengan ion $\mathrm{Ag}^{+}$[9] seperti terlihat pada gambar 3 .

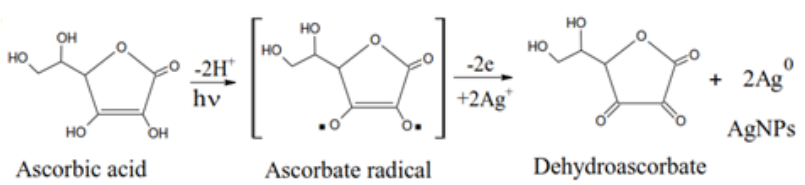

Gambar 3. Mekanisme reaksi pembentukan NPP dengan bantuan sinar matahari dan bioreduktor vitamin $\mathrm{C}$.

Warna pekat yang dihasilkan dari proses biosintesis NPP dengan menggunakan ekstrak buah 
M. calabura $L$ diduga akibat kandungan senyawa antioksidan pada buah $M$. calabura $L$ adalah besar dan tetap terjaganya senyawa antioksidan pada proses ekstraksi, sehingga senyawa antioksidan terekstrak secara maksimal. Dengan semakin banyaknya bioreduktor yang ada pada ekstrak, maka semakin banyak ion $\mathrm{Ag}^{+}$ yang tereduksi, sehingga NPP akan semakin banyak terbentuk, dan warna NPP terbentuk semakin pekat. Dalam penelitian ini dua parameter yang diamati untuk mendapatkan NPP yang optimum, yaitu waktu kontak reaksi dan perbandingan volume ekstrak buah kersen dengan larutan $\mathrm{AgNO}_{3} 1 \mathrm{mM}$.

Tujuan diamati waktu kontak dalam proses biosintesis NPP dengan ekstrak buah M.calabura $L$ adalah untuk mengetahui waktu optimum yang dibutuhkan untuk melakukan sintesis NPP. Sedangkan tujuan diamati perbandingan volume antara ekstrak buah $M$. calabura $L$ dengan larutan $\mathrm{AgNO}_{3} 1 \mathrm{mM}$ adalah untuk mengetahui perbandingan yang optimum dalam melakukan sintesis NPP. Kedua parameter ini trlihat dari nilai absorbansi yang tinggi, yang berarti NPP banyak terbentuk atau konsentrasinya tinggi sehingga keadaan tersebut akan sangat baik digunakan ke tahap uji dan aplikasi dari sifat NPP . Adapun variasi waktu kontak yang digunakan dalam penelitian ini adalah 5, 15, 30, 45 menit, 1, 2, 3 jam, 1, 2, 7 hari dan variasi perbandingan volume ekstrak buah $M$. calabura $L$ dengan larutan $\mathrm{AgNO}_{3} 1 \mathrm{mM}$ adalah $1: 3$, $1: 4,1: 5,1: 6$ dan $1: 7$, yang hasilnya Spektrum serapan NPP yang terbentuk mengerucut berada pada rentang panjang gelombang $400-450 \mathrm{~nm}$, yang menunjukkan bahwa NPP yang di-buat berhasil terbentuk. Waktu kontak terlihat mem-pengaruhi proses biosintesis, karena spektrum serapan NPP nilai absorbansinya cenderung naik seiring bertambahnya waktu.

Penentuan waktu kontak dan perbandingan volume optimum dilihat dari nilai absorbansi yang dihasilkan pada rentang puncak panjang gelombang 400$450 \mathrm{~nm}$ dan memiliki nilai absorbansi yang tinggi yang dibandingkan dengan setiap variasi. Selain itu dapat dilihat dari perubahan warna pada NPP untuk setiap masing-masing variasi waktu kontak dan perbandingan volume dengan melihat warna yang lebih pekat. Warna dapat menggambarkan nilai absorbansi NPP, semakin pekat warna NPP dari warna awalnya maka diindikasikan nilai absorbansinya semakin tinggi.

Pada variasi waktu kontak terlihat bahwa nilai absorbansi semakin naik seiring bertambahnya waktu. Akan tetapi waktu optimum ini akan digunakan untuk tahap uji selektivitas dan uji sensitivitas serta akan digunakan untuk aplikasi ke sampel yang membutuhkan waktu cukup lama. Hasil penelitian menunjukkan bahwa pada waktu 1 jam nilai absorbansi dari masing-masing variasi perbandingan sudah sangat tinggi dan selisih nilai absorbansi pada waktu 2 dan 3 jam tidak terlalu besar, maka waktu 1 jam diambil untuk menjadi waktu optimum pada proses biosintesis karena waktu 1 jam sangat efektif dan nilai absorbansinya sudah sangat tinggi.

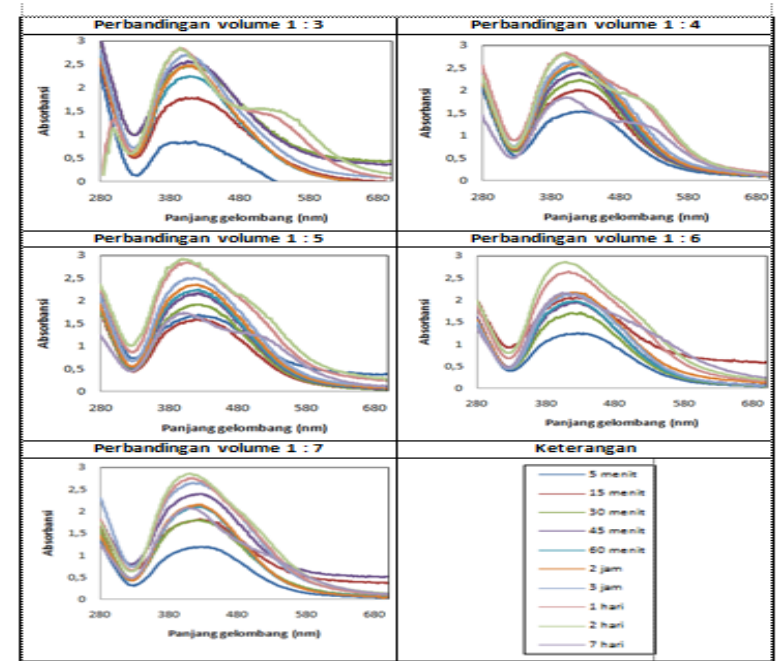

Gambar 4. Spektrum serapan spektrofotometer UV-Vis hasil biosintesis pengaruh waktu kontak dan perbandingan volume ekstrak buah M.calabura $L$ dengan larutan $\mathrm{AgNO}_{3} 1 \mathrm{mM}$

Pada penentuan waktu kontak optimum, maka perbandingan volume optimum ditentukan dari nilai absorbansi pada waktu 1 jam untuk setiap perbandingan volume. Dimana nilai absorbansi waktu 1 jam pada perbandingan $1: 3$ sebesar 2,241 , perbandingan $1: 4$ sebesar 2,541, perbandingan $1: 5$ sebesar 2,241, perbandingan 1 : 6 sebesar 1,970 dan pada perbandingan $1: 7$ sebesar 1,758. Dari hasil ini, dapat dilihat bahwa nilai absorbansi yang paling tinggi terdapat pada perbandingan volume $1: 4$. Sehingga dapat disimpulkan bahwa waktu kontak yang paling baik dan perbandingan volume yang paling tepat pada proses biosintesis NPP dengan ekstrak buah $M$. calabura $L$ yaitu pada waktu 1 jam dan perbandingan volume ekstrak buah $M$. calabura $L$ dengan larutan $\mathrm{AgNO}_{3} 1$ $\mathrm{mM}$ yaitu $1: 4$. Kondisi ini yang akan digu-nakan untuk membuat NPP pada tahap selanjutnya.

Pada uji selektivitas, NPP yang digunakan merupakan hasil biosintesis pada kondisi optimum. Konsentrasi masing-masing larutan logam sebesar 90,1 ppm sebanyak $0,2 \mathrm{~mL}$ ditambahkan ke dalam larutan NPP sebanyak $2 \mathrm{~mL}$. Data yang didapat dari pengujian secara spektrofotometri UV-Vis dapat dilihat pada Gambar 5.

Dari Gambar 5 terlihat bahwa pada penambahan logam Hg dapat dilihat bahwa larutan tidak lagi menunjukkan dalam bentuk NPP karena puncak serapan NPP menghilang dan menghasilkan kurva yang menurun mendekati spektrum serapan dari larutan $\mathrm{AgNO}_{3} 1 \mathrm{mM}$. Menghilangnya puncak serapan 
NPP disebabkan teroksidasi NPP oleh ion logam $\mathrm{Hg}^{2+}$ menjadi ion $\mathrm{Ag}^{+}$kembali.

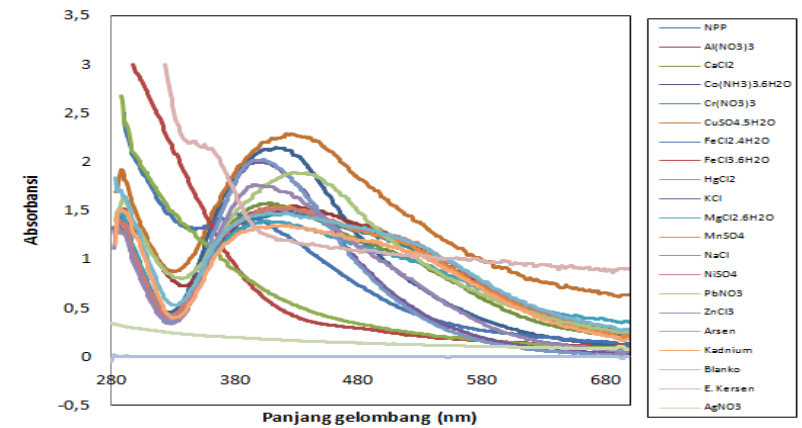

Gambar 5. Spektrum serapan spektrofotometer UV-Vis NPP + logam berat $90.91 \mathrm{ppm}(2: 0,2)$

Terjadinya reaksi oksidasi disebabkan nilai potensial reduksi $\mathrm{Hg} 2+$ lebih tinggi dari $\mathrm{Ag}+$, sehingga reaksi redoks $2 \mathrm{Ag}+2 \mathrm{Hg}^{2+} \rightarrow 2 \mathrm{Ag}^{+}+\mathrm{Hg}_{2}{ }^{2+}$ akan terjadi secara spontan [9]. Hal ini dapat dilihat pada Gambar 6.

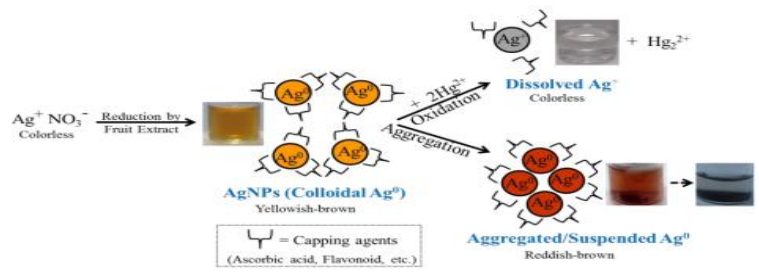

Gambar 6. Skema kemungkinan mekanisme dan ilustrasi interaksi NPP dengan ion $\mathrm{Hg}^{2+}$ [10]

Selain logam Hg, dari Gambar 4 dan 5 juga terlihat bahwa hampir semua logam mengalami perubahan warna dan mengalami perubahan spektrum serapan. Tetapi jika dilihat dari warnanya tidak jauh berbeda jika dibandingkan dengan warna yang berubah menjadi bening seperti pada penambahan $\mathrm{Hg}$.

Pada penambahan ion $\mathrm{Fe}^{3+}$ juga menyebabkan warna yang hampir bening dengan spektrum serapan turun mendekati spektrum serapan larutan $\mathrm{AgNO}_{3} 1$ $\mathrm{mM}$. Perubahan warna ini kemungkinan disebabkan karena potensial reduksi $\mathrm{Fe}^{3+}$ yang juga mendekati potensial reduksi dari $\mathrm{Ag}^{+}$sehingga terjadi reaksi redoks dan menurut [11] NPP dapat selektif terhadap ion $\mathrm{Fe}^{3+}$, karena kemungkinan reaksi reduksi oksidasi antara ion $\mathrm{Ag}$ dan $\mathrm{Fe}^{3+}$ yang menyebabkan perusakan pada NPP. Di sisi lain, NPP perak dapat selektif terhadap $\mathrm{Fe}$ disebabkan karena $\mathrm{Fe}^{3+}$ bereaksi dengan agen penstabil membentuk kompleks [12], karena flavonoid juga dapat berfungsi sebagai agen peng khelat logam karena adanya satu gugus kaboksil dan dua gugus hidroksil yang berdekatan bereaksi membentuk suatu kompleks yang stabil. Potensi tersebut ditunjukkan oleh posisi gugus hidroksilnya yang mampu menangkap radikalbebas dengan cara mengkhelat $\mathrm{Fe}$ sekaligus menstabilkan $\mathrm{Fe}$ [13].

Untuk logam $\mathrm{K}, \mathrm{Na}, \mathrm{Pb}, \mathrm{Zn}$ dan ion logam $\mathrm{Fe}^{2+}$ juga mengalami perubahan warna tetapi perubahan warna ini diperkirakan bukan karena terjadinya reaksi melainkan karena faktor pengenceran. Hal ini dibuktikan dari warnanya yang lebih pudar dari warna NPP dan spektrum serapannya menurun dari spektrum serapan NPP. Untuk logam $\mathrm{Al}, \mathrm{Ca}, \mathrm{Co}, \mathrm{Cr}$, $\mathrm{Cu}, \mathrm{Mg}, \mathrm{Mn}, \mathrm{Ni}$, As dan $\mathrm{Cd}$ memiliki warna yang pekat tetapi spektrum serapannya lebih rendah dari spektrum serapan NPP dan terdapat lekukan, hal ini kemungkinan disebabkan karena rusaknya NPP akibat penambahan logam tersebut.

Jadi dapat disimpulkan bahwa NPP hasil biosintesis ekstrak $M$. calabura $L$ selektif terhadap ion $\mathrm{Hg}^{2+}$ dan $\mathrm{Fe}^{3+}$ dengan sama-sama berubah warna secara signifikan menjadi bening dan spektrum serapannya juga berubah secara signifikan mendekati spektrum serapan larutan $\mathrm{AgNO}_{3} 1 \mathrm{mM}$.

Untuk mengetahui konsentrasi terendah dari logam merkuri yang dapat dideteksi oleh NPP hasil biosintesis ekstrak buah M.calabura L, maka dilakukan pengujian dengan mencampurkan NPP dan ion logam $\mathrm{Hg}^{2+}$ pada konsentrasi yang berbeda-beda, dibedakan untuk konsentrasi (ppm) dan (ppb). Konsentrasi (ppm) setelah pencampuran adalah $0 ; 0,3 ; 6,7 ; 13,3 ; 26,7 ; 30$; 33,$3 ; 50 ; 66,7 ; 83,3$ ppm dan konsentrasi (ppb) setelah pencampuran adalah $0 ; 0,7 ; 3,3 ; 6,7 ; 16,7 ; 33,3 ; 66,7$; 133,$3 ; 200 ; 266,7 \mathrm{ppb}$. Hasil uji untuk setiap variasi konsentrasi diamati secara manual dengan melihat perubahan warna dan secara spektrofotometri UV-Vis. Uji sensitivitas pada NPP dilakukan dengan mencampurkan NPP dan larutan Hg dengan perbandingan $2: 1$. Hasil uji dengan melihat spektrum serapan spektofotometer UV-Vis dapat dilihat pada Gambar 7. Spektrum serapan menunjukkan terjadi penurunan puncak sampai tidak adanya puncak serapan seiring dengan semakin besarnya konsentrasi. Hal ini kemungkinan karena NPP yang tersisa sangat sedikit akibat eroksidasinya NPP menjadi ion $\mathrm{Ag}^{+}$kembali oleh ion $\mathrm{Hg}^{2+}$ yang semakin bertambah, sehingga tidak lagi memiliki kemampuan menyerap cahaya pada panjang gelombang optimum secara maksimal. Untuk melihat sebatas mana NPP dapat mendeteksi logam Hg atau sensitif terhadap konsentrasi terkecil, maka hasil uji sensitif terhadap beberapa konsentrasi dari larutan $\mathrm{Hg}$ dibandingkan dengan hasil dari larutan $0 \mathrm{ppb}$ (blanko). 

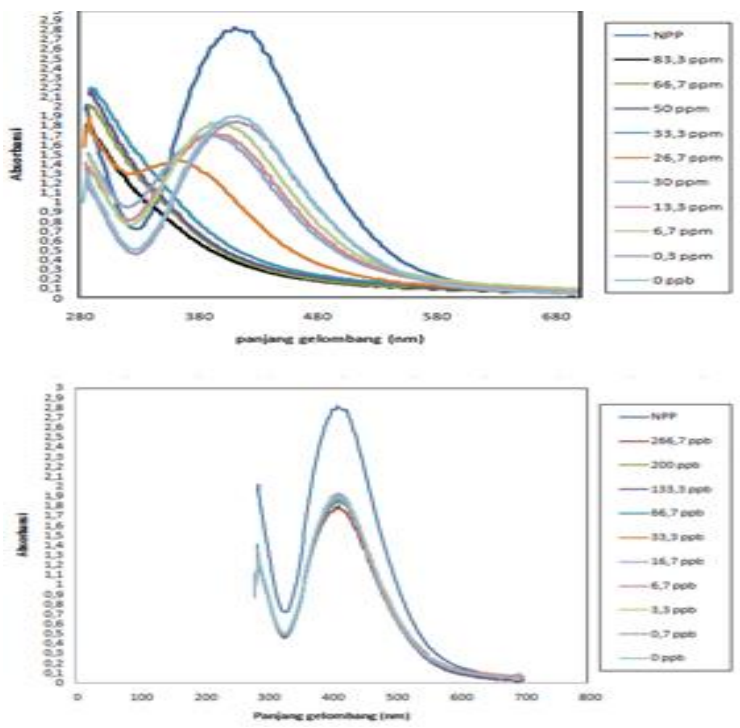

Gambar 7. Spektrum serapan spektrofotometer UV-Vis hasil uji sensitivitas

Jika dilihat dari spektrum serapan yang dibandingkan dengan spektrum serapan $0 \mathrm{ppb}$, maka NPP hasil biosintesis ekstrak buah $M$. calabura $L$ sensitif terhadap $\mathrm{Hg}$ sampai konsentrasi terendahnya yaitu $16,7 \mathrm{ppb}$.

Tujuan utama dari upaya membandingkan metode spektrofotometri UV-Vis terhadap metode citra digital adalah untuk menentukan tingkat keakuratan. Tingkat keakuratan ditentukan dengan cara memplotkan konsentrasi logam standar $\mathrm{Hg}$ metode spektrofotometri UV-Vis dengan persamaan $\mathrm{y}=$ $0,014 \mathrm{x}+1,953$ pada sumbu $\mathrm{x}$ dan konsentrasi logam standar $\mathrm{Hg}$ metode citra digital dengan persamaan $\mathrm{y}=$ 17,34x + 4,999 pada sumbu y. Hasil keakuratan di antara kedua metode tersebut dapat dilihat dari kelinieran garis lurus yang dihasilkan dari kurva seperti terlihat pada Gambar 8. Dari kurva terlihat bahwa nilai koefisien determinasinya sebesar 0,994. Nilai ini menunjukkan adanya hubungan yang linear antara metode citra digital dengan metode UV-Vis.

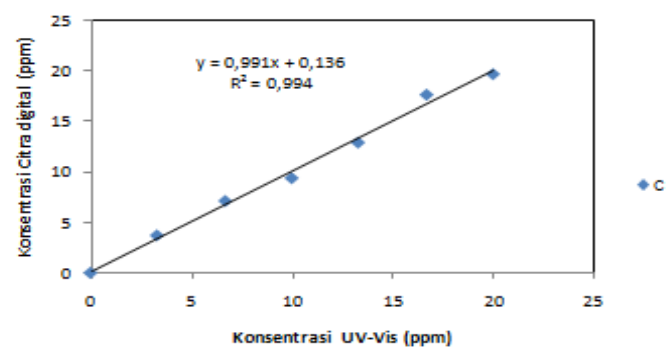

Gambar 8. Analisis keakuratan metode citra digital dengan UV-Vis diukur pada konsentrasi ppm

Hubungan kelinieran antara metode citra digital dengan UV-Vis menunjukkan bahwa metode citra digital dapat digunakan untuk mengganti metode
UV-Vis dalam analisis kuantitatif. Keakuratan metode citra digital terhadap UV-Vis sebesar 99,4\%. Jadi dapat disimpulkan bahwa metode citra digital memiliki akurasi yang tinggi untuk digunakan dalam menentukan kadar logam merkuri menggunakan NPP jika dibandingkan dengan metode UV-Vis.

Pengukuran juga dilakukan pada konsentrasi yang lebih kecil yaitu pada satuan ppb. Kurva kalibrasi yang didapat disajikan pada Gambar 9 .

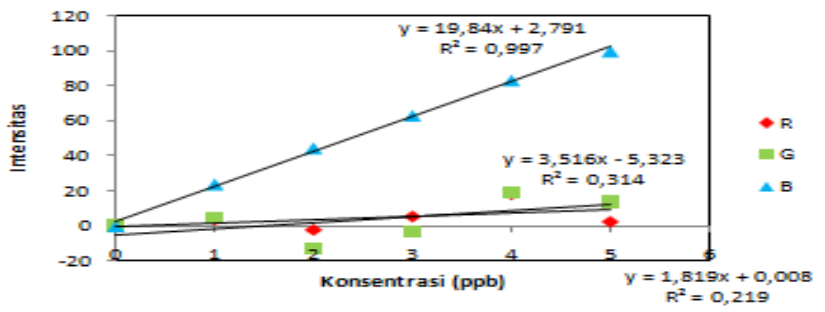

Gambar 9. Kurva kalibrasi konsentrasi vs intensitas $\mathrm{R}$ (red), G (green) dan B (blue)

Dari Gambar 9. terlihat bahwa kurva kalibrasi yang ditentukan dengan menggunakan metode citra digital hasilnya baik dengan memiliki nilai koefisien determinasi mendekati 1 yaitu 0,997 dan kemiringan yang tinggi yaitu 19,84. Jadi dapat disimpulkan bahwa citra digital akurat untuk metode analisis dan sensitif sampai dengan konsentrasi ppb.

\section{KESIMPULAN}

Dari hasil penelitian yang dilakukan dapat disimpulkan bahwa NPP yang dihasilkan dengan menggunakan ekstrak buah $M$. calabura $L$ mampu mendeteksi logam Hg. Semakin lama waktu kontak, dengan ekstrak, maka NPP yang terbentuk akan semakin banyak. Kondisi optimum dalam proses biosintesis NPP dengan bantuan ekstrak buah $M$. calabura $L$ terjadi pada waktu 1 jam dengan perbandingan volume $1: 4$. NPP hasil biosintesis ekstrak buah $M$. calabura $L$ sensitif terhadap logam $\mathrm{Hg}$ sampai dengan konsentrasi 16,7 ppb. Hasil uji perbandingan hasil metode spektrofotometer UV-Vis dengan metode citra digital menunjukkan bahwa keakuratan metode citra digital adalah sebesar $99,4 \%$ terhadap spektrofoto meter UV-Vis dengan kesensitifan konsentrasi hingga ppb.

\section{DAFTAR PUSTAKA}

[1] Riyadi, S. 2010. Analisis Kadar Merkuri (Hg) Di Dalam Krim Pemutih (Whitening Cream) dengan Menggunakan Alat Analisa Genggam Niton XL3t GOLDD+. Product Applicator . PT. Tawada Scientific. Diakses 29 Oktober 2016. 
[2] BPOM RI. 2007. Tentang Krim pemutih Mengandung Bahan Berbahaya dan Zat Warna yang Dilarang. No. KH.00.01.432.6081. 8(5):8 . ISSN : 1829-9334. Diakses 27 November 2016.

[3] Firdaus, M. L., Alwi,W, Trinoveldi,F, Rahayu, I, Rahmidar, L, Warsito,K, 2014. Determination of Chromium and Iron Using Digital Image-Based Colorimetry, Proc. Environ. Sci., 20, 298.

[4] Caro, C., Castillo, P.M., Klippstein, R., Pozo, D., Zaderenko, A.P. 2010. Silver Nanoparticles: Sensing and Imaging Application. University of Seville-UPO-Junta the andalucia-spain. Diakses 12 November 2016.

[5] BPOM RI. 2010. Peraturan Kepala Badan Pengawas Obat Dan Makanan Republik Indonesia. Tentang Bahan Krim pemutih. Nomor : Hk.00.05.42.1018 hal. 5 lampiran. Daftar Bahan Pengawet Yang Diizinkan Digunakan Dalam Krim Pemutih. Diakses 27 November 2016.

[6] Handayani, W. 2011. Pemanfaatan Tanaman Tropis Untuk Biosintesis Nanopartikel Perak dan Aplikasinya Sebagai Indicator Kolorimetri Keberadaan Logam Berat. Tesis :Repositori Universitas Indonesia : Jakarta. http://lontar.ui. ac.id .Diakses 15 November 2016.

[7] Rahman, M., Fakir, S.A., Rahman, M. 2010. Fruit Growth of ChinaCherry (Muntingia calabura). Botany Research International 3. ISSN 2221-3635

[8] L., Chen, Y., Chang, Chen, T., Yang, D. 2017. Food Function. DOI : 10.1039/C7FO00059F. Diakses 30 April 2017.
[9] Firdaus ML, Fitriani I, Wyantuti S, Hartati YW, Khaydarov R, McAlister JA, Obata H, Gamo T.. 2017b. Colorimetric Detection of Mercury (II) Ion in Aqueous Solution Using Silver Nanoparticles. Analyt. Sci, 33,800.

[10] Firdaus, M.L, Andriana, S, Elvinawati, Alwi, W, Swistoro, E, A Ruyani and Sundaryono, A. . 2017a. Green Synthesis of Silver Nanoparticles Using Carica Papaya Friut Extract Under Sunlight Irradiation and Their Colorimetric Detection of Mercury Ions, J. Phys: Conf. Ser., $817,012029$.

[11] Gao, X., Lu, Y., He, S., Li, X., Chen, W. 2015. Colorimetric detection of ironions (III) based on the highly sensitive plasmonic response of the $\mathrm{N}$-acetyl-L-cysteine-stabilized silver nanoparticles. Analytica Chimica Acta. ww w.else vier.com/

[12] Bothra, S., Solanki, J.N., Sahoo, S.K. 2013. Functionalized Silver Nanoparticles as Chemosensor for $\mathrm{pH}, \mathrm{Hg} 2+$ and $\mathrm{Fe} 3+$ in Aqueous Medium, Sensors and Actuators B: Chemical, http://dx.doi.org/10.1016/j.snb.2013.07.111.

[13] Harbone,J.B.,1987.MetodeFitokimia,Penuntun Cara Modern Menganalisis Tumbuhan. Terjemahan K. Phmawinata dan I. Soediro, ITB. Bandung.

Penulisan Sitasi Artikel ini ialah :

Sari, P.I, Firdaus, M.L, Elvia, R , Pembuatan Nanopartikel Perak (NPP) Dengan Bioreduktor Ekstrak Buah Muntingia calabura L Untuk Analisis Logam Merkuri, Alotrop, 1(1):20-26. 